\title{
An evolutionary approach to international political economy: the case of corporate tax avoidance
}

\section{Ronen Peter Palan ${ }^{1}$}

Published online: 26 June 2020

(C) The Author(s) 2020

\begin{abstract}
Corporate tax avoidance is both widespread and diverse in its practical mechanics. The scope of the phenomenon often leads economists to conclude that in the jungle of economic competition, tax planning (or optimisation) is among the necessary tools to ensure the survival of the fittest. This theory is increasingly associated with a Darwinian theory of economic evolution. In this paper, I develop a contrasting framework of the evolutionary political economy of corporate tax avoidance. Analysing core concepts of Old Institutionalist Economics (OIE), I examine the core drivers of corporate tax avoidance in a globalised system of states. The major contrast, I find, is between that of the corporate and legal personality and the institutional environment in which it operates. Historically, each corporate entity has been considered a separate legal person, yet a series of 'mutations' of incorporations laws created a widening gap between theory and reality, and these, in turn, give rise to tax arbitrage. Narrowing this gap, however, impinges on another venerable historical institution, the institution of sovereignty and sovereign inequality.
\end{abstract}

Keywords Old institutional economics · Tax avoidance · Multionational enterprise · Evolutionary theory $\cdot$ Sovereignty

JEL classification $\mathrm{B} 15 \cdot \mathrm{B} 25 \cdot \mathrm{B} 31 \cdot \mathrm{F} 5 \cdot \mathrm{F} 55 \cdot \mathrm{H} 26$

\section{Introduction}

In Patterns of Discovery, the historian Norwood Hanson argues that theories are built in reverse, retroductively. 'A theory is not pieced together from observed phenomena,' he writes. 'It is rather, what makes it possible to observe phenomena as being of a certain

Forthcoming: Review of Evolutionary Political Economy (REPE)

Ronen Peter Palan

Ronen.Palan.1@city.ac.uk

1 University of London, London, UK 
sort, and as related to other phenomena. Theories put phenomena into systems... A theory is a cluster of conclusions in search of a premise' (Hanson 1958, 90). In retrospect, I recognise such patterns in the relationship between empirics and theory in my own studies of offshore finance, tax havens and corporate tax planning (Palan 2006; Palan et al. 2013). Following a long period of desk research, I have ended up in possession of a cluster of conclusions about the underlying political and legal dynamics that brought about a sprawling offshore world. These conclusions, or 'answers', in Hanson's terminology, did not seat well with the theories that dominate my field of study, international political economy (IPE), rational institutionalism and Marxism. My quest for a theoretical framework that would reframe these answers as a coherent narrative led me in the direction of the work of Thorstein Veblen, John R. Commons and other members of a school of thought known as old institutional economics (OIE) or evolutionary economics. ${ }^{1}$ In this article, I retrace the intellectual journey that pointed out for me the value of the OIE scholarship to contemporary IPE.

Conventionally, taxation in general, and international business taxation more specifically, are understood as a classical public goods' problem of free riding. While everyone benefits from the provision of political stability and good infrastructure provided by the fiscal state, the individual taxpayer has incentives to free ride by minimizing taxation (Kudrle 2017). When it comes to the taxation of international business, the state is in a particularly weak position because markets are increasingly integrated (the globalization thesis), whereas politics remains territorial (the state system). As a result, states find themselves, on the one hand, competing with one another for high value-added economic sectors and capital investment. They do so by offering state-of-the-art infrastructure support, including political stability and good education, health, legal and transport systems, ramping ramp up public goods provisions (known as the 'competition state' thesis). On the other hand, mobile capital plays one jurisdiction against the other by gaining subsidies and tax holidays. The situation is exacerbated because in the case of taxation, governments suffer from first-mover disadvantage: they lay out 'precisely delineated rules, and then taxpayers are allowed to choose from this menu the transaction form most likely to reduce their tax bill' (Schizer 1999, 1349). In the arms race between mobile capital and immobile state, there can be only one winner (Avi-Yonah 2019). Under such circumstances, the typical solution to the problem of free riding - treating all beneficiaries as one consumer and then dividing the cost equally or making public good private-cannot work because sovereign state divides the consumer. As a result, the battle against corporate tax avoidance has tended to focus on the inter-state collective action problems, with the view of reducing capital's ability to play one against the other.

Not much is wrong with the above explanation. Only that there is a rather subtle problem which rationalist theoretical frameworks seem to not be attentive to. If the above explanation captures well the core dynamics of international business taxation and tax avoidance in 2019, would such accounts have been equally valid, say, 50 years ago, in the year of 1969 ? What about 1919, 1819 or 1619 ? And what about 2069? Most

\footnotetext{
${ }^{1}$ The OIE school is associated primarily with the works of Thorstein Veblen, John R. Commons and Wesley Mitchell, and some would add Joseph Schumpeter to the mix The second generation of OIE included many influential scholars in the New Deal administration, such as Alfred Berle, Gardiner Means but also Karl Polanyi and James Galbraith to name a few. For discussion, see (Commons 1990; Dosi 2000; Gruchy 1990; Hodgson 2007; Scott 2013).
} 
would agree that the world was very different in 1619, in 1819 and perhaps even in 1919; and while the above account may capture certain trends observable already 50 years ago, it may be of limited use today. The account of dilemmas faced by states, regulators and the like are, in other words, time-specific. However, how does change come about? When and how does it affect the core dynamics of international business taxation? Does the change in the dynamics of international business taxation arise from forces that are entirely exogenous to business or not? These are the sort of questions that have been answered, and in my view, cannot be answered, within the bounds of theories that understand the dynamics of change in terms of interaction between fixed entities (the 'state', 'corporation,' 'capital', 'rationality', 'actor'), but require instead, an evolutionary sensibility of the kind, I argue, provided by the OIE school.

For presentation purposes, my retroductive reading of the dynamics of change in the offshore world is inverted. I begin by presenting my interpretation of Veblen and Commons' ideas, centring in particular on those ideas and concepts that I found useful in my studies of the offshore world. I start, therefore, with a brief outline of those OIE ideas and concepts that proved useful, leading towards my interpretation of the core drivers of corporate tax avoidance in a globalised system of states.

\section{Evolutionary economics as an IPE theory}

If truth is to be told, OIE does not immediately appear to be a promising candidate for the development of an evolutionary theory of International Political Economy. Many, including sympathetic commentators, consider the work of OIE scholars to be a little more than a collection of insightful, if highly individualised bodies of work, lacking the necessary degree of coherency or consistency to be considered a distinct approach to political economy (Blaug 1997; Rutherford 2000). Others condemn the OIE School for failing to set up a clear issue-related agenda (see Arrow in Williamson 2000). But even if these objections are exaggerated, a big 'if' no doubt, original OIE scholars had little to say about geopolitics, transnational economic relationships or any other questions that are associated with contemporary IPE. Veblen was strongly influenced by US congressional investigations into corporate America's malfeasances. John R. Commons was a labour economist and his approach has tended to be highly legalistic. Westley Mitchell was interested more in physics than biology, and among his other achievements, established the National Bureau of Economic Research in the 1920s. There is, therefore, considerable intellectual ground to be covered to just ensure that OIE work is of some relevance to contemporary IPE, let alone served as paradigmatic contender to existing approaches.

To begin this intellectual journey, I believe, it is best to start with the broader philosophical discussions about the rise of evolutionary thought in biology, beginning with the core aspects of Darwin's 'dangerous idea' (Dennett 1996). On this, most commentators agree: evolutionary theory is not what is popularly understood to be 'Darwinism', or some 'universal struggle for existence, [whereby] the right of the strongest prevails' (Spencer, quoted in Knutsen 1997, 168). Darwin did not talk about the laws of the jungle. At its radical core, Darwin's theory offered the most profound rejection of the philosophical foundation not only of physics and science prior to 
Darwin but also of the vast majority of contemporary social sciences as well known otherwise as Platonic essentialism (Cziko 1997; Dennett 1996; Mayr 1982).

Prior to Darwin, writes Mayr, "the great majority of naturalists believed that species were immutable productions, and had been separately created" (Mayr 1982, 4). Darwin rejected these axiomatic assumptions, change, he argued, arises not from interaction among fixed entities but in the evolution of the species themselves. In doing so, Darwin, in effect, reversed the logic of the core puzzle of biology. Instead of seeking to explain how change came about in interaction between organisms whose essential characteristics were fixed, Darwin asked how thermodynamically dissipative bodies maintained some cogency and a sense of closure in flux. As Richard Dawkins puts it: "Darwin's 'survival of the fittest' is really a special case of a more general law of survival of the stable" (Dawkins 2016, 18). Evolutionary theory, therefore, is not about how change arises over time, but it is a theory that seeks to explain the phenomena of stability in condition of a flux. If rationalism assumes that the world is fundamentally, orderly (typically designed that way by some omnipotent presence), and change arises in transitory disequilibrium, then evolutionary theory assumes that our world, including our social world, is in constant flux, struggling to maintain a semblance of order.

Two points are of relevance here. First, Darwin's rejection of Platonism arose out of time scale reframing. What appears as fixed and stable, unchanging, within the context of a human time scale reveals itself to be fluid and changing under a different time scale. In this, Darwin had allies in the emerging field of geology. Evidence to the fluidity of the apparently stable topography of the earth shook both the discipline of biology and geology to their very foundations. It was an earthquake in thought, an epistemological revolution, whose effects rippled (and still do) through the entire gamut of biological and social sciences (Gohau 1990; Monroe and Wicander 2011).

Second, his epistemology pointed to a different 'unit of analysis' for the fledgling field of biology, shifting the focus of investigation from the organisms to species. Darwin introduced a mode of thought, argues Liane Gabora, that 'involves relinquishing our focus on the individual' (Gabora 1997, 34) - something that we are grappling with still today. It was an approach that centred on the 'population as a unit of organization. The population is an entity, subject to its own forces, and obeying its own laws... in this important sense, population thinking involves ignoring individuals: it is holistic, not atomistic' (Sober 1980, 370).

To the best of my knowledge, neither Veblen nor Commons discussed Darwin's epistemological innovations. Yet, I consider both to be evolutionary thinkers in the Darwinian mode because their approach was predicated on similar time scale reframing, and the introduction of population thinking into the social sciences. Like evolutionary biologists, they relinquished the individual as their preferred 'unit of analysis'. But instead of opting for some version of structuralism, typically, the alternative unit of analysis that has emerged in late nineteenth century discussions to counter the rise of methodological individualism, they have introduced a wonderfully original and creative solution, arguing that institutions are the equivalent of the specie in the social world. Social institution took centre stage in their thought, as the prism through which all observable phenomena were interpreted. Evolutionary social science, they argued, is the study of institutional interaction in historical time.

So here, we have it. OIE reframed the core puzzle of social, political and economic theory as a question of institutional stability in condition of flux. If conventional 
political theory is predicted on the assumption that change arises from interaction between fix 'entities,' classified as 'individuals', 'states' or 'corporations.' The OIE approach would rather inquire those entities maintained their sense of 'individuality', their 'statehood' or their 'corporateness' in condition of flux. A point that is well understood by Ian Lustick, evolutionary social scientist, he writes:

explains that contingent structures (political scientists would say "institutions") commonly taken as ontologically fundamental and permanent, such as "species" (or states), are more accurately understood as clouds of similarity or patterns of stability with respect to which we have rather stable sets of expectations. The boundaries of such structures are functions of previous patterns of adaptation at lower levels of analysis, the constraints and incentives of circumstances, and the sedimentation of historical accidents (Lustick 2011).

In other words, the stability of any 'unit' is transient, and in itself, is a product of the institutional environment.

\section{Institutions and institutional change: a theory of action}

The OIE approach rejected, therefore, both Weberian methodological individualism and Durkheimian structuralism and sought to develop a third way, a genuine evolutionary theory of the social science. Not surprisingly, a lot of what OIE had to offer hinges on their definition of institutions. Here, we encounter our first serious debate among different streams of institutionalism. Veblen refers to institutions as the 'settled habits of thought common to the generality of man' $(1919,239)$. Whereas for Commons, institutions are 'collective action in control, liberation and expansion of individual action' (Commons 1931, 648). Such pervasive definition of institutions had been criticised for lack of precision, if not for being outright unhelpful, contrasted, so the argument goes, with the far more precise approach to institutions introduced by public choice theory, as well as the new institutional economics (NIE). ${ }^{2}$

It might be worth retracing the conceptual rationale for the NIE's conception of institutions in order to appreciate the reasons Veblen and Commons opted for an alternative. Drawing on Dilthey's interpretation of the core values of science, Weber, along with the Austrian school (and against, among others, Marx), reasoned that the only admissable facts of social inquiry are universally shared observations (because they are the equivalent of the scientists' ability to repeat results in laboratory conditions). And the only shared objects of observations in social inquiry, Weber argued, are individuals and their 'action.'

This hypothesis is a core tenet of what had become known as methodological individualism. Kenneth Arrow, for instance, interpret the primacy of the individual to mean that " $[\mathrm{t}]$ he individual in the economy and in the society is like the atom in

\footnotetext{
${ }^{2}$ NIE is associated primarily with the works of Ronald Coase, Oliver Williamson, Douglas North, Nelson and Winters and Elinor Ostrom. For discussion, see (Coase 1998; Congleton 2007; Hall and Taylor 2016; Menard 2005; Williamson 2005). NIE occupies an intermediate position between standard (or neoclassical) and heterodox (evolutionary) theories in economics. I discuss NIE at greater length in chapter three.
} 
chemistry; whatever happens can ultimately be described exhaustively in terms of individuals involved' (Arrow 1994, 3). Recognising, of course, that individual action is always constrained by someone, the common solution to such predicament had been the assumption that societal constraints arose out of the action of other individuals pursuing broadly similar goals.

Methodological individualism in Arrow's world, therefore, is a description of change as interaction among rational individuals facing constraints on their freedom posed by other individuals who are, in turn, pursuing similar goals. This is the founding epistemology of standard economics as well as what is called 'rationalism' in the field of International Relations and International Political Economy (Milner 1998). I would argue that standard economics and political science, more or less up to about the time of the seminal work of Roland Coase (mid-1950s, when his ideas began to gain traction) assumed, just as Robert Keohane would argue many years later (in applying these theories to international relations) that systemic constraints on individual's ability to maximise utility arose from the action of other individuals pursuing broadly similar goals (Keohane 1988).

Arrow's interpretation of methodological individualism is not shared by all, even those considered 'rationalists.' Von Hayek, for instance, considered Arrow's position as 'pseudo-individualism' (Hayek 1948). He agrees that 'there is no other way towards an understanding of social phenomena but through our understanding of individual actions directed towards other people and guided by their expected behaviour' (Hayek 1948 , 6). Yet this argument, he continues, 'is directed primarily against the properly collectivist theories of society which pretend to be able directly to comprehend social whole like society, etc., as entities sui generis which exist independently of the individual which compose them' $(1948,6)$. Oliver Williamson went further in rejecting simplified version of individualism. The Walrasian fiction, 'the idea that economics operate out of an 'institution free core,' is highly misleading (Williamson 1999). For at every level of economic analysis, every action takes place within a dense environment of norms, customs, mores, rules and institutions. There is little doubt that the centre ground of rationalist economics and political science has shifted by now from Arrow's nominal individualism towards a recognition of institutions as 'an independent variable' (Putnam et al. 1994, 8).

Williamson, Putnam and others hold on to a methodological individualist core, while seeking a nuanced understanding of environmental constraints. Individual preferences entail the ordering of alternatives based on their relative utility, a process that, in turn, results in an option choice. Actions is constrained, however, 'the rules of the game in a society or, more formally, the humanly devised constraints that shape human interaction' (North 1990). ${ }^{3}$ But such theory could only mean that observable individual action contains element of individual preferences which are based, say, on taste, price consideration, availability of goods and so on, combined with an element of response to institutional constraints. Put differently, we cannot assume, as some methodological individualists seem to do, that action is a pure expression of some inner core set of

\footnotetext{
${ }^{3}$ Not everything is lost in terms of strict methodological individualism. One could argue that those institutional constraints come to us from the past, as congealed outcomes of individual interactions - a theory that is very difficult to verify. Ultimately, it does not matter how those constrains came about.
} 
preferences. In other words, action itself is a composite and cannot be a formative unit of analysis of social investigation.

John R. Commons had anticipated many of these objections. Commons accepted Weber's notion of the importance of shared observation in scientific inquiry but argued that observed behaviour is not an appropriate unit of analysis of social inquiry. His criticism centred on the lack of appreciation of the roles played by institutions, but rather on the epistemological foundations of methodological individidualism. Rather than serving as foundational concept, he argued, observed 'action' is largely shaped by 'collective action', which was his defintion of institutions. Observable 'action' is in fact 'trans-action'-representing the preferences and choices made by indivdiuals based on their subjectively perceived sense of the array of opportunities, penalties and rewards presented by their institutional environment. In his words, 'individual actions are really transactions instead of either individual behaviour or the "exchange" of commodities" (Commons 1990, 143). Hence, for Commons, the unit of analysis of economic and social theory is the transation - a concept that was then adopted, and corrupted by, among others, Ronald Coase (Coase 1998).

\section{Institutions and transactions as the foundation of institutional thinking}

'Transactions' - the core concept in OIE's cosmology - take place between at least two persons, and are governed by certain rules, which are provided by the 'collective action in control of individual action' (or institutions). Further reading of Commons suggests that the term 'control' is perhaps too strong because of its connotations with coercion. Collective actions, or institutions, do not generally control individual action; they provide the environment or context of 'working rules' that are subjectively internalised by individuals (and other legal personalities, such as the state or corporations). Working rules do not only constrain but also enable action.

A critical aspect of Commons' evolutionary approach and the notion of institutional enabling of transaction is the theory that institutional rules are inherently ambiguous. He summarised his ideas with his famous notion of the 'four verbs':

Stated in language of the operation of working rules on individual action, they are expressed by the auxiliary verbs of what the individual can, cannot, must, must not, may or may not do. He "can" or "cannot," because collective action will or will not come to his aid. He "must" or "must not," because collective action will compel him. He "may," because collective action will permit him and protect him. He "may not," because collective action will prevent him (Commons 1990, 649).

In other words, observed transactions (as opposed to Weberian 'action' or Arrow's 'social atoms') reflect the way individuals and other legal persons transact with one another, believing they follow rules that tell them what they can, cannot, must, must not, may or may not do. In other words, even when following rules, individuals still have a lot of choices to make. These ideas are echoed today by behavioural economists (Kahneman 2011). 
This theory has a lot of nuance. To begin with, the more verbs we add to our theory of the working rules, the greater the likelihood that individuals, including legal persons such as corporations, will have to choose how to comply with those verbs. Some may stress those working rules that tell them what they 'can' and 'cannot' do, while others may be more interested, say, in the rules specifying what they 'may' or 'may not' do. Transactions are informed by these working rules, but it is well known, for instance, that financial innovation in common law countries is largely a play on the 'may' or 'may not' rules of finance, accounting and other regulatory standards. Since different individuals are, in effect, choosing their own hierarchy among those rules, those ruleor institutions - do not only constrain behaviour, and certainly do not 'control' behaviour, but they inform and 'enable' observed behaviour. Why, then, focus exclusively, as NIE does, on institutions as constrains and not as enablers of transaction (Crawford and Ostrom 1995; Jupille et al. 2003; Scott 2013)?

Second, the act of choosing compliance among the different aspect of the working rules of society is not entirely individualised. For Veblen, it is based largely on what he calls, 'habits of thought', the morals, norms, and customs of the age. Indeed, Veblen appears to define institutions as 'settled habits of thought'. Hence, habits of thought-a concept to which I return below-is a critical component of OIE. It is an idea that is almost entirely absent in NIE theory.

Third, if this was not complicated enough, Commons then adds a crucial addendum. I would call it the heterogeneity principle. Since institutions are the equivalent of the 'specie' in biological thought, institutions as species interact with other institutions in the social realm. This theory implies that individuals are 'members' of several institutions and at any given moment in time are subject of diverse 'rules of the game' of those collective action in control of individual action. There is a certain degree of individual bias and selection, or freedom, to choose not only among those 'verbs' but also to choose which of those rules of which institutions they primarily abide by-be they the family, the state, the corporation, religion, the mafia and the like.

It follows that transactions are subject to a plurality of conflicting rules, and hence are far more heterogeneous than assumed by analytical theories. Such 'loose' theory of transaction allows plenty of scope for innovation, emulation and adaptation, the social equivalent of evolutionary mutations - and that is exactly what Veblen and Commons wanted to retain by adopting an expansive definition of institutions.

The notion of heterogeneity and choice is an important point to which I will come back in my analysis of the rise of offshore. Standard economics and political science, as well as Marxian thought, tend to treat the social environment with a set of totalising concepts. Terms such as 'markets', 'capitalism,' the 'system of states' - allude to an environment that is homogenous even at the very global level. Hence, 'action' is explained with the aid of one set of rules (called 'theory'). In the words of Photis Lysandrou:

The general equilibrium assumptions underpinning mainstream macroeconomic theory act to eliminate the future as a distinct time frame altogether... Although the future does have a meaningful existence in mainstream finance theory it does so merely as an intermediary medium through which equilibrium is achieved (Lysandrou 2016, 464).

In standard economics, there is no sense in which the 'actors' (for instance, corporations) evolve over time - they merely adjust to the price mechanism. 
Is the situation better with Marxism? I do not think so. In Marxist thought, capitalism may evolve through stages, but neither the capitalist nor capital seem to have change much since Marx wrote in his Capital volume one. The twenty-first century capitalist is still the same 'owner of means of production' as his equivalent (sic), the nineteenth century capitalist. Capitalism seems to be going through endless cycles of phases, and stages. Nothing learned, nothing gained; nothing changes (in principle).

From an evolutionary perspective, however, the global environment is highly heterogeneous, and most explanations, including the theory I proposed about the rise of the offshore world, are centred on evolution that takes place precisely because of environmental heterogeneity and the co-existence of so many institutions in one space.

\section{An evolutionary theory of institutions change}

Economic transactions take place within a heterogeneous space of co-habiting institutions. That space needs defining because it is the equivalent of the rationalist spatial categories of states, markets, capitalism and the like. In other words, that space shapes, in aggregate, the environment, and as such, it shapes the nature of what will be interpreted as systemic constraints placed on individual transactions.

Commons distinguishes between two broad types of institutions, customs and 'going concerns.' There are great deals of 'unorganised customs,' he argues, aggregations of cultural memes that clump together to make our cultural habitats. The institution of shaking hands, for instance, on a deal. Then, there are other institutions that we call 'organizations', or 'going concerns. ${ }^{4}$ The latter have evolved in the modern world into 'legal persons', something to which I turn below. Like higher biological organisms, 'going concerns' are considered by OIE scholars as amalgams that 'ingest' great many unorganised customs and memes, as well as other going concerns, and those help shape the specific character of those going concerns.

Commons defines a going concern as 'a joint expectation of beneficial bargaining, managerial, and rationing transactions, kept together by working rules and by control of the changeable strategic or limiting factors which are expected to control the others' (Commons 1990, 58). Going concerns are important, first and foremost, because they transcend individual life span: 'individuals come and go, but the concern goes on, if not in one form, then in another' (Chavance 2012), 30). In addition, going concerns provide something that unorganised customs are unable to explicit and enforceable rules, including protocols for change and adaptation. There are close affinities between this theory and the typical analysis of formal organizations. Foss and Klein, for instance, define organizations as "coordinated action among individuals who differ in the dimensions of interests, preferences, and knowledge (Foss and Klein 2013, 518).

Institutionalists, whether of the NIE and OIE persuasion, are also broadly in agreement that going concerns (or organizations) present islands of relative stability

\footnotetext{
4 'A social unit that organizes and controls individuals and directs them towards a common purpose. They limit individual discretion but provide a security of expectations because they shape customary and expected behaviour. In addition to limiting individuals, going concerns expand the ability of the individual to act. These concerns are governed by working rules, which change in the face of new circumstances' (Atkinson 2009, 434.)
} 
in a sea of flux. But stability comes at cost, limiting individual discretion while providing, in return, security in expectation and reduction in transaction and information cost. There are also important differences among institutionalists. OIE constructs a heterogenous sphere whereby individuals (or other going concerns as well) inhabit many institutions simultaneously. Since they do, 'going concerns' have to put a great degree of investment in the narrative of closure - and the investment in those narratives often trumps what would be considered rational or desirable course of action. This is another way of saying that evolutionary theory is a special case of the survival of the stable. The stability of social categories that standard rationalist theory takes as given, comes, according to evolutionary theory at great cost and requires a great degree of energy. Put simply, a great deal of investment must be made to maintain stability of a going concern. Paradoxically, investment in narratives of closure can sometimes prevent going concerns from pursuing ruthlessly what might be considered their interests, including, as we will see below, the supposed desire of states (which are legal persons and going concerns) to tax their corporations.

I am putting the cart before the horses. In order to comprehend the rationality of what may be ultimately irrational action we need to return to theory. The theoretical implications of the above discussion are that what social scientists call social 'structure' is nothing but the agglomeration of all those institutions, customs and going concerns. Social structures are the effect of a degree of coherence imposed on a heterogeneous social space largely by an imposing 'going concern' (for instance, the state). But that is insufficient. Due to the inherent plurality of the social field, another glue is needed to create a semblance of coherency to the world 'out there'. Veblen stresses that the glue, and a necessary façade of coherency, in an institutionally heterogeneous world is that very notion of 'habits of thought' to which I referred above.

The concept of habits of thought is interesting. Habits of thought are collective human experiences and observations that congeal into collective narratives about the nature of the world. At any given historical time, habits of thoughts represent the common sense understanding of the world, taken as 'factual' or undisputed truthsonly to be replaced in time by other truths, other indisputable facts. Habits of thoughts are evolving perspectives of values, norms and ethics and the way of seeing how the world works; they are the cosmologies that hold together disparate institutions under more or less common narrative. Evolution in 'habits of thought' is recognised very clearly once we change our time scale frame from years and decades, to that of centuries and millennia. The 'habits of thought' of the ancient Greeks or the Aztecs had, presumably, the same hold on their imagination the rationalist habit of thought has on us. 5

The theory takes us back, therefore, to the epistemological time scale reframing at the heart of evolutionary theory. From an OIE perspective, what sociologists think of social structure is an impression generated within a human period that results from interaction between leading going concerns, habits of thoughts and congealed institutions. Change the period from hours, day, weeks and years to centuries and millennia,

\footnotetext{
5 That is at least the way I understand Michel Foucault's highly original the Order of things. In the preface to the book Foucault writes: 'This book first arose out of a passage in Borges, out of the laughter that shattered, as I read the passage, all the familiar landmarks of my thought - our thought, the thought that bears the stamp of our age and our geography..'(Foucault 2018, Xvi). The Order of This is an audacious attempt to develop a theory of evolution and change in the habits of thoughts of society.
} 
and each aspect of the 'social structure', including the very structure, is in a flux. Most states disappear as we go backward in time, and then the very institution of state disappears as well. Human nature, alas, is far more in flux than assumed, down to concept and perception of time, taste even colour. Umberto Eco had a lot to say about these things (Eco 2010).

\section{Towards an evolutionary model of social and political change}

Another interesting dimension to what sociologists call social 'structure' is Veblen's theory of capital. The typical narrative of late nineteenth century placed the 'capitalist' as an entrepreneur and an innovator at the heart of social change. Marx did not challenge this image but suggested that industrial capitalism would generate unbridgeable conflict between owners and workers. Veblen developed an original approach that led him in a direction of a more radical critic of capitalism without adopting the tendencies of Marxist utopia. According to Veblen, capital consists of the sum total of society's knowledge, knowhow, institutions and habits of thought (Veblen 1908) in a way capital is always 'social capital'. Every single technological product or invention draws on countless prior human technological and organizational innovations that ultimately go back to the dawn of humanity. Capital is, therefore, neither quantifiable nor divisible, nor is it a specific innovation of 'capitalism.'

Two ideas flow from the above. First, capital is, in essence, 'intangible'. It is the knowhow and belief systems, the rules and the laws of society. Capital 'accumulation' does not refer, therefore, to the accumulation of 'things', but to the accumulation of knowledge, institutions, knowhow, what broadly can be described as 'habits of thought.' Second and consequently, distributional battles occur not over capital (it is difficult to separate knowledge), but over the fruits of capital. ${ }^{6}$ In every society - that is, in every historical configuration of social institutions - certain techniques emerge for the appropriating the fruits of capital and distributing them, unequally. Veblen called these techniques, 'cornering'. In his words, 'it becomes worth-while... for the individual with the strong arm to engross, or "corner," the usufruct of the commonplace knowledge of ways and means' (Veblen 1908, 525).

Cornering, according to Veblen, is historically contingent on the prevailing technological, environmental conditions and habits of thought of a given period. If strongmen controlled trade routes in the medieval world, as the technique of cornering that worked at that time, today's 'strongmen' control intangible capital directly, devising schemes and laws that allow them control over the fruits of knowledge, including technology, through the legal techniques of property rights, and appropriate their material value unequally. In Commons' words, the theory of 'holding' property as turned in the twentieth century into a practice of 'withholding' or sabotage (Nesvetailova and Palan 2020).

This concept of structure and capital has implications to the theory of the 'rational individual' or rational 'legal person'. From an institutional evolutionary perspective,

\footnotetext{
${ }^{6}$ In any known phase of culture, this common stock of intangible, technological equipment is relatively large and complex, i.e. relatively to the capacity of any individual member to create or to use it, and the history of its growth and use is the history of the development of material civilization (Veblen 1908, 521).
} 


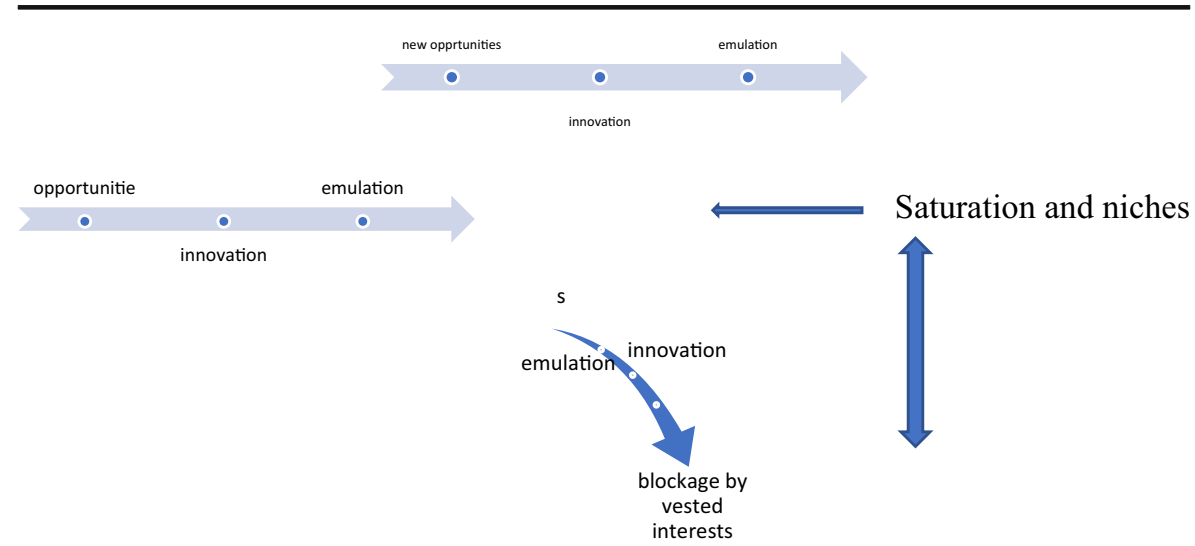

Fig. 1 Principles of evolutionary change

individuals (or corporate individuals, i.e. going concerns) are rational to the extent that they observe and survey the complex agglomeration of rules (the four verbs), customs and norms, in which they inhabit, seeking as it were to identify potential opportunities, penalties and rewards. Veblen talks of opportunities for creation, innovation and industry, of opportunities for 'cornering' and sabotage, opportunities for status differentiations and the like. Some individuals are better predisposed to innovate and create; others are more interested in cornering or might seek status differentiation.

Some individuals or going concerns discover, by hasard or by innovation, advantageous paths within the institutional makeup that could be advantageous for 'cornering' greater portion of the fruits of capital. If a discovery of new innovation or path is rewarded materially or otherwise, it is likely to be exploited, and exploitation leads to emulation. As growing number of individuals and going concerns emulate the innovation, their collective action in aggregate can alter those environmental conditions that gave rise to the opportunities in the first place may change. In effect, a new set of opportunities, penalties and rewards systems would ensue. In this way, change comes about as cumulative causation but without the necessary collective action or intent, as assumed by the rationalist model (see Fig. 1). Figure 1 represents my interpretation of evolutionary change. This is the theory I use to analyse the drivers of contemporary corporate tax avoidance.

Last word before we descend from this high level of abstraction to more concrete level of analysis, adapted as it were, to the issues facing IPE today. It should be clear by now that OIE have introduced, if only implicitly, an important analytical distinction between a theory of causation and a theory of constraints. Social and political evolutions are constrained to a degree by the nature of inherited institutional history and structure. OIE agree with that. However, causation, the cause of human transaction, in contrast, lies largely in the future. Transactions are future oriented and are motivated by some estimates or anticipation of future realities. However, since the future is never known, and can only be imagined and anticipated, the motive for action can only be attributed to some imagined future. Historical analysis can never predict the future, but only produce retrospective interpretation.

OIE analysis centres, therefore, on the core tension between causation and constraint, between the past (constraints) and the future (causation). The present order, 
which appears on the surface stable (or fairly stable), is flux. It is in a permanent tussle between, on the one hand, constraints presented by existing institutional setups and contemporary habits of thought and, on the other, anticipation of potential opportunities and rewards. That is the theoretical framework that is as useful in sociology or economics as it is in International Political Economy.

\section{The IPE of going concerns}

The field of IPE is interested primarily in two types of going concerns: states and firms. What is, then, the advantage of the above formulations vis-à-vis the more conventional notions of states and markets as conflicting techniques of resource allocations (Easton 1953)? Conventionally, markets represent decentralised mode of allocation; whether politics is centralised and organised through hierarchies? Let us start with the state, an important player, of course, in the construction of the offshore world. There are states that serve as offshore financial centres, those who supposedly oppose to them. Indeed, the regulatory environment of international business taxation is provided by states.

Commons argues that the diversity of institutions, and the resulting heterogeneity of the social field, beget problems that require the formation of a specialised governance going concerns. There is, therefore, a special type of going concerns, authorizing concerns, 'collective action in control of violence' (Commons 1924, 74). Like all going concerns, states are 'intangible.' They are held together through a circular network that binds together unorganised customs, going concerns and habits of thought. States survive over time by developing narratives of past, present and future, founded on principles of organizational closure, and carried out or 'performed' by 'hosts', natural individuals. States cohabit with other institutions in relations of dominance and delegation: they authorize the rules of the game, but they are also subject of rules as well. There is considerable investment, therefore, in the principle of closure, or what IR scholars call 'narrative of identity'. States are embedded, in turn, in an environment that consists of a medley of institutions, including, of course, other states.

For Commons, sovereignty is not a fixed theory or a doctrine, but an ever shifting and evolving social institution that had become central to the running of modern states. The institution of sovereignty evolved within a broader historical context of mutations in narratives of authority (i.e. itself consist of series of institutions that provide the answer to questions like, why should have a delegated authority; why should we obey that authority; how authority is delegated, in other words, the legitimacy of delegation of power) and narratives of closure (who is a member of my group? What makes 'my group' a group?). Historical institutions of authority and delegation of power, and institutions of closure, glued as it were, in today's habits of thought, and combined in one aspect of the modern notion of sovereignty.

But habits of thought evolve, and with them so does the prefered narrative of closure. For good, well-known reasons, the hierarchical narrative of sovereignty was placed under enormous stress already in the eighteenth century, and was pulled assunder during the early nineteenth century. In the new rendering, the DNA remained but the 'people' had replaced God as the sovereign 'absence-presence' in the narrative 
of social closure. But in doing so, an hierarchical and possibly rationale authoritative narrative tilted horizontally, and in doing so the entirey logic of authority became circular. As Veblen notes with his usual cynicism:

This divine right of princes was disallowed among the more civilized peoples on the transition to modern ways of thinking, and the sovereign rights of the prince were taken over - at least in form and principle - by the people at large (Veblen 2005, 88).

In the new schema, the people as a collective became simultaneously both the subject and the rulers. They were the subject of their own - a total circular argument whereby the gluing 'absence-presence,' the entity that rulers appeal to, are the very people they are ruling. This is nothing but an absurdity. But as Veblen notes, it seems to work.

Habits of thought, however, do have concrete implications for people's life. As 'people' were in a new scheme of soveriegnty both rulers and subjects, it 'made sense' in the evolving habit of thought that clear criteria or a boundary is needed to establish who is in and who is out. After all, those 'in' are the rulers (and also the majority of the subjects). The political system had to know concretely who are the 'rulers', and had therefore to separate the 'people' that are rulers/subjects, from other 'people.' The logic of the situation dictated, therefore, different relation between territory and space - all of which appears to modern eyes so obvious and self-evident, we tend to forget how relatively new they are.

\section{Sovereignty of property rights}

One aspect of this sovereign reordering has mostly been under the radar. But it proved very important. The sovereign state, acting in the name of the 'people,' set about to redefine its boundaries by populating its territory with 'things' that are subject of its sovereignty. To begin with, natural persons were redefined as 'citizens', bearers of rights and duties. They are given identity cards, passports etc. These processes ensured, on the one hand, that state knows who exactly are 'club-members' in whose name it was ruling. The state would also know who were 'its' subjects. In turn, the system of citizenship allowed individuals to move between the newly erected boundaries of the discrete state system.

In the new scheme, it was important that corporate persons were given licences of incorporations and right to trade, and began to be treated as discrete legal nodes subject to rules, privileges and responsibilities as defined by the law of the state (Robé 2011). Other going concerns, for instance, the family, are inscribed (or delegated) with a degree of sovereignty as discrete nodes that have certain rights and duties with the bound of the law. Children up to a certain age are assigned the status of dependents on their citizen-parents - their rights vis-à-vis their parents defined by law. Citizens of other countries are also recognised by the state as discrete nodes and bearers of rights and duties.

In many advanced countries, certain categories of livestock and domestic pets are also recognised as discrete entities and part of the furniture of the discrete territorial space. They are subject to registration by the state and are given legal status and protection. Vehicles of any kind - cars, airplances, ships, cranes, you name it - are required to register with a state, and often must display evidence of registration at all 
times as number plates, flags and so on. All ocean-going vehicles, ships or yachts, including stationary oil rigs and the like, are each registered by a state and carry a flag - although by a queer twist of legal innovation, they are often flying flags of states that have very little to do with. Those who do not carry flags are branded pirates. Aircrafts and air balloons and the like are licensed by states as well. In fact, each and every trade, past and future, every contract imagined, signed and agreed formally and in some jurisdictions, orally, in the web of trillions of implicit and explicit contractual relationships that undergird the web of economic transaction we call 'market', is sanctioned by a state, adjuctaed by a state (which could be different from the licensing state), and considered taking place within a territorially circusmcribed territory.

This is a new world. Discretization of the territorial space is a product of the late nineteenth century political movements, and the logical outcome of the evolution in the theories of closure, the institution of sovereignty and modern habits of thought. The effect of the process of discretization, drilled down to each and every aspect of economic transactions, is paradoxical. On the one hand, each and every economic contract is invested, supported and sustained by the modern concept of sovereingty. Every contract is assigned to a territory, subject to the rules and regulations of that territory. Pull sovereignty out of its mooring, and the attendant concepts, the theories and narratives that prop up our modern habits of thought, begin to drift. Frankly, in that case, the value of property assets, most of which are intagibles, is in danger of melting away into thin air. In other words, all the money in the world, what we call 'wealth', which, according to Veblen is human capital, the sum total of humanity knowledge and knowhow, capitalised and traded based on anticipiated future earnings, hinges on that very circular theory of sovereinty, a useful absurdity. That ensures, in turn, that a lot of interests are vested in the circular theory of sovereignty, and its alligned aspect of narrative of closure: the theory of the 'people'; theory of sovereign equality and the like. Sovereign coding is, therefore, an essential ingredient lubricating the world economy.

At the same time, just as the world had been moving in the direction of narrative and practices that affected discrete territorial closure, the dominant theory, the dominant habits of thought, as Veblen would call them, shifted markedly in favour of market opening, ease of movements of goods, capital and people across borders. Economic theory maintained that the 'people,' in whose name states ruled, were better off if capital and goods were allowed to be exchanged freely and without hinderance. Indeed, the people, in whose name states ruled, were better off if the state kept its distance fom the economy. States that genuinely ruled in the name of the people, and who, on the one hand, had to ensure they knew who are the people that are ruling them and created the necessary apparatus of borders and legal assignments in support of that goal, were now required to break down the very boundaries they erected so that the 'people' would enjoy the advantages of being rulers.

Economists viewed the new type of states as consumption-ownership arrangements that in turn function like a Buchanan' club good (Buchanan 1965). The members of these consumption-ownership arrangements are citizens and the registered corporate organizations, the so-called domestic constituency. Whereas other stakeholders include a non-domestic constituency (such as a foreign investors), transnational organizations, multinational corporations or transnational religious or cultural organizations, and other states and international organizations. The state as a club good provides certain 
privileges to its members at cost - chiefly among them is tax. A certain tension was already visible between the notions of sovereignty as a sacred dimension of people's life, and between profane, utilitarian concept of sovereignty.

\section{Corporate avoidance and sovereign splitting}

The main vehicles of internationalisation, or flow, proved to be the other type of going concerns, corporate going concerns. Business entities displaying many corporate characersticis existed in India as early as 800 BC (calles Sreni). Most scholars, however, trace the institutional DNA of the joint stock companies of the 16th and 17th centuries Europe not to India, but to three Roman institutions, the Collegia, Corpora and Societates (Wright 2013, 19). From inauspicious beginnig in the 16th and seventeenth century, a number of corporate entities reached enormous size in comparision to the overall size of the economy at the time. These corporations were dealt a serious blow by a wave of speculation and fraudulent promotions in the beginning of the eighteenth century, known collectively as the South Sea Bubble. The Bubble Act of 1720, passed by the British Parliament, "permitted to issue transferable shares" (Pearson 2005).

The result of the act was that corporations were few and far between not only in Britain but also in the USA and Europe, requiring a Royal Charter, act of Congress or Act of Parliament. Corporation law evolved slowly and hesitantly in the nineteenth century, with the USA taking the lead. The first general corporations law is credited to the State of New York in 1823 (Lindholm 1944), although that law was applicable only to manufacturing corporations. Additional laws were introduced in the UK and the USA further liberalising laws of incorporation. In an 1886 important ruling, in Santa Clara v. Southern Pacific Railroad, the US Supreme Court declared corporations as "persons," thus coming under the purview of the Fourteenth Amendment. By the last quarter of the nineteenth century, British courts were also beginning to recognise the concept of "corporate personality" (Couzin 2002, 12). Since these mometous decisions, the American legal system and those of the Western world generally, have been founded on what is called 'entity law', a doctrine that treats each corporate entity in an affiliated group as a separate juridical person, even when owned and controlled by other corporations with which in conducts a common business enterprise (Adriano 2015; Blumberg 1993; Lambooy et al. 2013; Robé 2011).

While for historical reasons, each corporate entity is considered a separate legal person, a series of 'mutations' of incorporation laws creatted an ever-widening gap between theory and reality. By late nineteenth century, the state of New Jersey introduced a number of enabling clauses to its chartering laws that permitted corporate groups to own shares in other groups (Grandy 1989). The laws were then emulated by other states such as Delaware, Vermont and then adopted world-wide (Arsht 1976; Cheffins 2015; Manesh 2011). The new laws of incorporation saw almost immediately an acceleration of industrial concentration and the speedy growth of businesses of much greater complexity and scale. Firms grew to enormous size through mergers and acquisition, and by establishing corporate groups with parent corporations, subholding companies and hundreds if not thousands of subsidiaries and affiliates most of which were organised as limited liability entities (Avraham et al. 2012; Desai 2009; 
Robé 2011). The law, however, still treats each individual corporate entity as separate and independent (Blumberg 1993), whereas MNEs are controlled and managed centrally (Fleming et al. 2014; Robé 2011). A gap opened up between entity law, the treatment of each corporate unit as a separate legal personality, as opposed to centralised group decision-making (Gordon 2016; Palan 2006; Robé 1995, 2011). Put differently, whereas strictly, each corporate entity is a separate legal personality, the New Jersey law of incorporation and its derivations around the world, allowed, in effect, for these legal persons to be controlled by another legal persons located in different jurisdiction.

These features of incorporation laws became particularly important in light of developments in corporate tax as well. The growing number of corporate legal persons were supposed, among other things, to pay tax. As often is the case, narrative of taxation had to evolve in conujnction with the 'habits of thoughts' tied to existing narratives of closure, sovereignty and the role of the corporate personality. Different jurisdictions developed different doctrines, in effect storylines, that would serve as the basis for corproate recognition and taxation. In time, those narratives proved highly important.

In the British case, tax was levied on income from sources in the UK (Couzin 2002, $1-2)$. This is not a problem if corporations operated in one jurisdiction, but as some began to internationalize, the issue of the location of the corporation for tax matters had to be clarified. British courts took the lead in developing a doctrine that tied together, in a logical and consistent manner, a theory of the legal personality of the corporation, and a theory of the location of the corporation, so that tax liabilities would be clear. The Courts opted to use the metaphor of natural person to clarify those issues.

The problem was brought into sharp relief with regard to companies operating in the British Empire and beyond. The Inland Revenue, the authority entrusted with the collection of taxes, had to clarify where corporations resided for tax purposes, brought several cases to the courts to clarify these issues. One major decision dates back to 1876 , when judges were confronted with the case of two companies, the Calcutta Jute Mills and Cesena Sulphur Mines, both registered in England but whose production activities were located respectively in India and Italy. In these cases, the judges applied the 'great principle of the law of England in relation to taxation is that taxation shall only be imposed upon persons or things actually within this country (Quoted in Couzin 2002, 6).

The judges in these two cases argued that 'things actually within this country', the place where the corporate legal person resides was akin to the location to natural person's vital organs. Limbs could be cut off, but the person survives, the head and the heart could not be removed. Hence, by analogy, the location of the corporate head and heart, management and financial affairs, is where the corporation resides. In the case of the Calcutta Jute Mills and Cesena Sulphur control and management were carried out outside of England. Hence, the court concluded the two companies were not resident in Britain for tax purposes and should not be taxed in Britain. The place of registration (or "seat," as it is understood in continental law) was not deemed necessary to prove residence; rather, effective control was the necessary proof. The principle was reaffirmed in 1901 in a "seminal decision steeped in history" (Couzin 2002, 38). The renowned diamond multinational De Beers registered in the Colony of the Cape of Good Hope in 1888, and located its head office in Kimberley in the Cape, maintained nonetheless an office in London chaired by Cecil J. Rhodes. The judges concluded that 
real control of the company's strategy was executed from London, and hence, De Beers should be taxed in England.

In 1904, the British company Egyptian Delta Land and Investment Co. Ltd. was established to purchase and lease land in Egypt and moved its board of directors to Cairo. The issue of the company's place of residence for taxation went to court in 1929. This time around, judges decided that the company was not liable for British taxation. The decision meant that foreign companies could register in the UK, but if they organised their activities abroad, they would not be subject to UK taxes. This proved to be a seminal case. "The decision in Egyptian Delta Land created," writes Sol Picciotto, "a loophole which in a sense made Britain a tax haven: foreigners could set up companies in the UK, which would not be considered UK resident under British law because they were controlled from overseas, but might be shielded from some taxation at source because they were incorporated abroad" (1992). As the decision applied to the entire British Empire, it was soon exploited by Bermuda, the Bahamas and later the Cayman Islands and Hong Kong.

The results of these developments were that these supposedly separate legal persons could be located in one jurisdiction, and subject to its rules and regulations, but controlled through majority share-holding by interests located in another jurisdiction. The New Jersey legal mutation gave management legal tools to creates all sorts of techniques of ownerships and control of purpotedly independent legal personalities held through chains of ownerships sometimes five, ten or even more deep. Some jurisdictions followed the British legal theory of taxation and could allow, under certain circumstances, the licensing of non-tax resident corporate entities. The gap that opened up between one set of institutions - entity law - and another - ownership rules - had the inevitable outcome of two incommesurate global norms and values (or 'habits of thought'), potentially in conflict with one another.

The narrative of closure of tilted sovereignty works on the assumption that each territorial space is separate and discrete, filled in by legal personal and contractual arragements sanctioned by the state. But the mutation of incorporation laws allowed for things located in one jurisdiction to be controlled by legal persons located in another. The gap between rules and regulations in one country can, and is often used, to arbitrate rules of taxation, regulation of other countries to the benefit of the MNE and its shareholders. For instance, in one famous case of the Apple Inc., which became the subject of two in-depth investigations, one by the Levine Congressional Committee in the USA, and one by the European Commission (Barrera and Bustamante 2018; European Commission 2016; Levin et al. 2013). The two investigations found, in the words of the EU Commission, that

The Apple Group includes companies incorporated in Ireland. Among the companies of the Apple Group incorporated in Ireland, a distinction can be made between companies [which are both,] headquartered in Ireland and are also tax resident in Ireland... and companies that are incorporated in Ireland but are not tax resident in Ireland (European Commission 2016, 2.1.2, 45).

Apple had decided to pass on many rights over patents and trademarks to these Irish non-tax resident entities. But since these subsidiaries were registered in Ireland, they had were tax resident elsewhere either, ending therefore, as tax resident nowhere and 
not pay tax. A considerable portion of Apple's non-US income had been accumulated in those tax nowhere entities. The Levine Committee and the EU Commission both reached the conclusion that Apple's complex arrangement with its Irish special purpose entities could be classified as a tax avoidance scheme - although still denied by Apple and by the Irish government (Barrera and Bustamante 2018).

\section{Conclusion}

Students often asked why do members of the OECD group of nations allow tax havens and offshore financial centres to flourish? Why do they allow the Apples of this world to arbitrate national rules and avoid paying tax? Why the OECD, the UN, the EU, the USA and the rest introduce series of rules and legislations that have the effect only of creating additional complexities, but never touch the core? Why is this endless cat and mouse game between regulators and the corporate world? Many jump to the conclusion that politicians are either collaborate with big capital, and they are 'captured' by business? How else can we explain inaction, inertia and failed attempts at resolving the problem 'once and for all?'

The OIE approach presents, credibly, a different story. The contemporary techniques of corporate tax avoidance are taking advantage of 'gaps' that opened up in the regulatory system which in itself emerged as a product of the institutional makeup and habits of thought of nineteenth century European societies. Perhaps, most significant contribution of an OIE approach to these discussions is the insight that the key to changing dynamics of international business taxation do not lie in new regulations, but in the effect of the new regulations might have on the stability of the authorizing going concern, the state. There is an increasing awareness that effective legislation can only be introduced in ways that will have profound implications to the narratives of closure and habits of thought that are at the very core of contemporary order. One solution to corporate tax avoidance would require harmonization of corporate tax laws across the world. But this, in turn, would imply some limitations on the notion that the 'people' are the sole sovereign over the 'people.' Such propositions may be acceptable under an extension of an emerging 'habits of thought' that view states increasingly as club-extension (such as the EU). More importantly, as sovereignty is increasingly being used as a commercial weapon, the link between sovereignty and the concept of the 'people' becomes tenuous. Sovereignty can evolve, for instance, in the direction of municipal sovereignty in which states are seen no longer seen as territorially discrete entities, but more of administrative units whose primary purpose is to deliver efficient goods to a territory. Alternatively, the primacy of the people may be re-asserted at costs to market opening and free movement. This way or that, the interaction between localised innovations, both in avoidance and regulation, and larger frame evolution in institutions and habits of thought, will determine such matters. This, I believe, is the important insight that evolutionary theory brings to IPE.

Acknowledgements I would like to thank Amin Samman, Hannah Petersen, Richard Phillips, Jean-Phillip Robé, Mark Herman Schwartz and, in particular, Anastasia Nesvetailova for their help in support in developing the ideas for this article. Research for this article benefitted from the generous support of two funding projects: Eurppean Ressaearh Council Advanced grant agreemet 694943 (CORPLINK) and an EU Horizon 2020 grant agreement 727145. 
Open Access This article is licensed under a Creative Commons Attribution 4.0 International License, which permits use, sharing, adaptation, distribution and reproduction in any medium or format, as long as you give appropriate credit to the original author(s) and the source, provide a link to the Creative Commons licence, and indicate if changes were made. The images or other third party material in this article are included in the article's Creative Commons licence, unless indicated otherwise in a credit line to the material. If material is not included in the article's Creative Commons licence and your intended use is not permitted by statutory regulation or exceeds the permitted use, you will need to obtain permission directly from the copyright holder. To view a copy of this licence, visit http://creativecommons.org/licenses/by/4.0/.

\section{References}

Adriano EAQ (2015) The natural person, legal entity or juridical person and juridical personality. Int Aff 4(1): 363-75

Arrow KJ (1994) Methodological individualism and social knowledge. Am Econ Rev 84:1-9. https://doi. org/10.2307/2117792

Arsht SS (1976) A history of Delaware Corporation Law. Del J Corp Law 1:1

Atkinson G (2009) Going concerns, futurity and reasonable value. J Econ Issues 43:433-440. https://doi. org/10.2753/JEI0021-3624430216

Avi-Yonah RS (2019) Globalization, tax competition and the fiscal crisis of teh welfare state: a twentieth anniversary retrospective. Presented at the taxation adn globalization, IDC, Herzliya

Avraham D, Selvaggi P, Vickery JI (2012) A structural view of U.S. bank holding companies (SSRN scholarly paper no. ID 2118036). Social Science Research Network, Rochester

Barrera R, Bustamante J (2018) The rotten apple: tax avoidance in Ireland. Int Trade J 32:150-161. https://doi. org/10.1080/08853908.2017.1356250

Blaug M (1997) Economic theory in retrospect, 5th edn. Cambridge University Press, Cambridge; New York

Blumberg PI (1993) The multinational challenge to corporation law: the search for a new corporate personality. Oxford University Press, Oxford

Buchanan JM (1965) An economic theory of clubs. Economica 32:1-14

Chavance B (2012) John Commons's organizational theory of institutions: a discussion. J Institutional Econ 8: $27-47$

Cheffins BR (2015) Delaware and the transformation of corporate governance. Del J Corp Law 40:1

Coase R (1998) The new institutional economics. Am Econ Rev 88:72-74. https://doi.org/10.2307/116895

Commons JR (1924) Legal foundations of capitalism. Transaction Publishers, London

Commons JR (1931) Institutional economics. Am Econ Rev 21:648-657

Commons JR (1990) Institutional economics. Vol. I: Its Place in Political Economy. Transaction Publishers

Congleton RD (2007) Elinor Ostrom, understanding institutional diversity. Public Choice 132:509-511. https://doi.org/10.1007/s11127-007-9157-x

Crawford SES, Ostrom E (1995) A grammar of institutions. Am Polit Sci Rev 89:582-600. https://doi. org/10.2307/2082975

Couzin R (2002) Corporate residence and international taxation. IBFD, Amsterdam

Cziko G (1997) Without miracles: universal selection theory and the second Darwinian revolution. MIT Press, Cambridge

Dawkins R (2016) The selfish gene. Oxford University Press, Oxford

Dennett DC (1996) Darwin's dangerous idea: evolution and the meanings of life, New edn. Penguin, London

Desai MA (2009) The decentering of the global firm. World Econ 32:1271-1290. https://oi.org/10.1111 j.1467-9701.2009.01212.x

Dosi G (2000) Innovation, organization and economic dynamics: selected essays. Edward Elgar Publishing, Cheltenham

Easton D (1953) The political system: an inquiry into the state of political science. Knopf, New York

Eco U (2010) History of beauty. Random House Incorporated, New York

European Commission (2016) COMMISSION DECISION of 30.8.2016 ON STATE AID SA.38373 (2014/C) (ex 2014/NN) (ex 2014/CP) implemented by Ireland to Apple (decision no. C(2016) 5605 final)

Fleming JCJ, Peroni RJ, Shay SE (2014) Formulary apportionment in the U.S. international income tax system: putting lipstick on a pig. Mich J Int Law 36:1

Foss NJ, Klein PG (2013) Organizational governance, in: the handbook of rational choice social research. Stanford University Press, Stanford 
Foucault M (2018) The order of things. Routledge, Abingdon

Gabora L (1997) The origin and evolution of culture and creativity. Journal of Memetics - Evolutionary Models of Information Transmission 1:1-17

Gohau G (1990) A history of geology. Rutgers University Press, New Brunswick

Gordon R (2016) Increasing use of tax-transparent entities by private groups due to BEPS. Tax Spec 19:136

Grandy C (1989) New Jersey corporate chartermongering, 1875-1929. J Econ Hist 49:677-692. https://doi. org/10.1017/S0022050700008810

Gruchy AG (1990) Three different approaches to institutional economics: an evaluation. J Econ Issues 24: 361-369. https://doi.org/10.1080/00213624.1990.11505034

Hall PA, Taylor RCR (2016) Political science and the three new institutionalisms. Polit Stud

Hanson NR (1958) Patterns of discovery: an inquiry into the conceptual foundations of science. Cambridge University Press, Cambridge

Hayek FA (1948) Individualism and economic order. University of Chicago Press, Chicago

Hodgson GM (2007) The revival of Veblenian institutional economics. J. Econ. Issues 41:324-340. https://doi.org/10.1080/00213624.2007.11507019

Jupille J, Caporaso JA, Checkel JT (2003) Integrating institutions: rationalism, constructivism, and the study of the European Union. Comp Polit Stud 36:7-40. https://doi.org/10.1177/0010414002239370

Kahneman D (2011) Thinking, fast and slow. Farrar, Straus and Giroux, New York

Keohane RO (1988) International institutions: two approaches. Int Stud Q 32:379-396. https://doi. org $/ 10.2307 / 2600589$

Knutsen TL (1997) History of international relations theory. Manchester University Press, Manchester

Kudrle R (2017) The limited prospects for international tax cooperation - Kudrle - 2017 - global policy - Wiley online library. Glob Policy 8:455-463

Lambooy TE, Diepeveen RA, Nguyen K, Foort S v ‘t (2013) The opacity of a multinational company's organization, legal structure and power. Dovenschmidt Q 1:121-133

Levin C, Pryor ML, Landrieu ML, McCaskill C, Tester J, Baldwin T, Heitkamp H, McCain J, Johnson R, Portman R, Paul R, Ayotte K, Bean EJ, Roach RL, Katz DH, Goshorn DJ, Kerner HJ, Hall S, Patout BM, Wittman SD, Robertson MD (2013) Permanent subcommittee on investigations 304

Lindholm RW (1944) The corporate franchise as a basis of taxation. University of Texas Press, Austin

Lustick IS (2011) Taking evolution seriously: historical institutionalism and evolutionary theory. Polity 43 : 179-209. https://doi.org/10.1057/pol.2010.26

Lysandrou P (2016) The colonization of the future: an alternative view of financialization and its portents. J Post Keynes Econ 39:444-472. https://doi.org/10.1080/01603477.2016.1245583

Manesh M (2011) Contractual freedom under Delaware alternative entity law: evidence from publicity traded LPs and LLCs. J Corp Law 37:555

Mayr E (1982) The growth of biological thought: diversity, evolution, and inheritance. Harvard University Press, Cambridge

Menard C (2005) A new institutional approach to organization, in: Handbook of new institutional economics. Springer, Boston, pp 281-318. https://doi.org/10.1007/0-387-25092-1_13

Milner HV (1998) Rationalizing politics: the emerging synthesis of international, American, and comparative politics. Int Organ 52:759-786. https://doi.org/10.1162/002081898550743

Monroe JS, Wicander R (2011) The changing earth: exploring geology and evolution. Cengage Learning, Boston

Nesvetailova A, Palan R (2020) Sabotage: the business of finance. Penguin, London

North DC (1990) Institutions, Institutional Change and Economic Performance. Cambridge University Press, Cambridge

Palan R (2006) The offshore world: sovereign markets, virtual places, and nomad millionaires. Cornell University Press, Ithaca

Palan R, Murphy R, Chavagneux C (2013) Tax havens: how globalization really works. Cornell University Press, Ithaca

Pearson H (2005) Origins of law and economics: the economists' new science of law, 1830-1930. Cambridge University Press, Cambridge

Putnam RD, Leonardi R, Nanetti RY (1994) Making democracy work: Civic traditions in modern Italy. Princeton University Press, Princeton

Robé J-P (1995) L'entreprise en droit. Droit Société 29:117-136. https://doi.org/10.3406/dreso.1995.1322

Robé J-P (2011) The legal structure of the firm. Account Econ Law 1. https://doi.org/10.2202/21522820.1001

Rutherford M (2000) Understanding institutional economics: 1918-1929. J Hist Econ Thought 22:277-308. https://oi.org/10.1080/10427710050122521 
Schizer DM (1999) Sticks and snakes: derivatives and curtailing aggressive tax planning. South Calif Law Rev 73:1339

Scott WR (2013) Institutions and organizations: ideas, interests, and identities. SAGE Publications, New York Sober E (1980) Holism, individualism, and the units of selection. PSA Proc Bienn Meet Philos Sci Assoc 1980:93-121

Veblen T (1908) On the nature of capital. Q J Econ 22:517-542. https://doi.org/10.2307/1884915

Veblen T (2005) The vested interests and the common man, abridged edn. Cosimo Classics, New York

Williamson OE (1999) The mechanisms of governance. Oxford University Press, Oxford

Williamson OE (2000) The new institutional economics: taking stock, looking ahead. J Econ Lit 38:595-613

Williamson OE (2005) Transaction cost economics. In: Handbook of new institutional economics. Springer, Boston, pp 41-65. https://doi.org/10.1007/0-387-25092-1_4

Wright RE (2013) Corporation nation. University of Pennsylvania Press, Philadelphia 